\title{
Çocuklar İçin Yeme Davranışları Ölçeğinin Türkçe Geçerlik ve Güvenirliği
}

\author{
Meltem KÜRTÜNCÜ*, Nurten ARSLAN**
}

Öz

\begin{abstract}
Giriş: Yeme davranışı, yemek yeme ve yeme zamanını içeren biyopsikososyal kökenli karmaşık bir davranıştır. Amaç: Bu çalışma, engelli çocuğa sahip aileler tarafından değerlendirilen Çocuklar İçin Yeme Davranışları Ölçeği'nin (The Children's Eating Behavior Inventory/CEBI) Türkçe eşdeğerliğini sağlamak, geçerlik ve güvenirliğini belirlemek amacı ile yapılmıştır. Yöntem: Ölçek için çeviri geri çeviri yöntemi, içerik geçerliği için kapsam geçerlik indeksi, yapı geçerliği için açıklayıcı ve doğrulayıcı faktör analizi yapılmıştır. Ölçek güvenirliğini test edebilmek için Cronbach alfa değeri, madde toplam korelasyonu kullanılmıştır. Ölçeğin test tekrar test güvenirliği 72, iç tutarlılı̆̆ ve yapı geçerliği ise en az iki çocuklu eşi ile birlikte yaşayan engelli çocuğa sahip 190 ebeveynden toplanan veriler ile belirlenmiştir. Bulgular: Ölçeğin Cronbach’s alfa değeri .77 olup ölçek genel kabul görür düzeyde güvenilir olarak belirlenmiştir. Faktör analizi sonucuna göre; ölçeğin 5 faktör altında toplandığı, açıklayıcılık katsayısının \%65.05 olduğu görülmüştür. Verilerin faktör analizi için uygunluğunu değerlendirmede kullanılan Kaiser-Meyer-Olkin değeri .71'dir. Bartlet Küresellik Testinde $\mathrm{x}^{2} / \mathrm{df}=1370.545 / 171$, p<.001 olup veriler faktör analizi için uygun görülmüştür. Doğrulayıcı faktör analizi sonuçlarına göre kabul edilebilir ve iyi uyum göstermektedir ( $\mathrm{p}=.001 ; \mathrm{p}<$.01). Sonuç: Çocuklar İçin Yeme Davranışları Ölçeği'nin Türkçe formunun iki ebeveynli, en az iki kardeşe sahip engelli çocukların yeme davranışlarını değerlendirmek için geçerli ve güvenilir bir ölçek olduğunu göstermiştir.
\end{abstract}

Anahtar Kelimeler: Çocuk, Yeme Davranışı, Ölçek, Geçerlik ve Güvenirlik.

\section{Abstract
Validity and Reliability of the Turkish Form of the Eating Behavior Scale for Children}

Backgraund: Eating behavior is a complex biopsychosocial behavior involving eating and eating time. Objectives: The aim of this study was to determine the validity and reliability of Turkish Children's Eating Behavior Inventory which was evaluated by families with disabled children. Methods: Translation and back-translation were used for the adaptation of the scale. Content validity index was employed for content validity, while exploratory and confirmatory factor analyses for construct validity. Cronbach's alpha coefficient and item-total correlation coefficient were used to test the reliability of the scale. Test-retest reliability of the scale was 72 , internal consistency and construct validity were determined by data collected from 190 parents with disabled children living with their spouses with at least 2 children. Results: The Cronbach's alpha value of the scale was .77 and the scale was generally accepted as reliable. According to factor analysis; The scale was gathered under 5 factors and the explanatory coefficient was 65.05\%. Kaiser-Meyer-Olkin (KMO) sample adequacy measurement value .71 is used to evaluate the suitability of the data for factor analysis. The Bartlet Sphericity Test was $\mathrm{x}^{2} / \mathrm{df}=1370.545 /$ $171, \mathrm{p}<.001$, and the data were considered appropriate for factor analysis. Acceptable and good fit according to confirmatory factor analysis $(\mathrm{p}=.001 ; \mathrm{p}<.01)$. Conclusion: The Turkish version of the Children's Eating Behavior Inventory was a valid and reliable scale for assessing the eating behaviors of children with disabilities with two parents and at least two siblings.

Key Words: Child, Eating Behavior, Scale, Validity and Reliability.

Geliş tarihi: 03.01.2020 Kabul tarihi: 30.09.2020

$\mathrm{Y}$ eme davranışı, yemek yeme zamanını içeren biyopsikososyal kökenli karmaşık bir davranıştır. Yeme davranışları sorunları özellikle çocukluk çağında her yaş grubunda olup, sağlıklı, hasta ve gelişim geriliği olan çocklarda görülebilmektedir (1-3). Sağlıklı çocuklarda bu durumun daha az görüldüğg̈nü ve gelişim geriliği olan çocuklarda bu durumun daha fazla olduğunu gösteren çalışmalar mevcuttur (1-6).

Yaşamın ilk yıllarında özellikle çocuğun sağlıklı büyüme ve gelişmesi için gerekli olan en temel şey sağlıklı beslenmedir. Çocukluk çağında yaşanan beslenme ve yeme davranışı sorunları yaşamın diğer yıllarına da taşınır $(2,3)$. Çocuğun beslenme gereksinimlerinin karşılanması, yeme zamanı ve yeme sorunlarının giderilmesi hem çocuğun gelişimi hem de ebeveyn-çocuk ilişkisi açısından önem taşımaktadır $(1,3,7)$.

Beslenme sorunu yaşayan çocuğa sahip ebeveynlerde stres ve anksiyete görülür. Ebeveynlerin yaşadığı stres ve anksiyetenin çocuğun beslenme zamanını olumsuz yönde etkilediğini gösteren çalışmalar mevcuttur (4,7-13). Anneler çocukların beslenme zamanındaki yaşadığı çatışmalar nedeniyle çocukları ile aralarındaki ilişkide zorlanabilir $(4,7,10,12,13)$. $\mathrm{Bu}$ durum normal gelişim gösteren sağlıklı çocuklara kıyasla gelişim geriliği olan çocuklarda daha yaygındır $(1,6,7,14,15)$.

Yeme davranışları anne-çocuk arasındaki ilk etkileşimin temeline odaklıdır. Bu etkileşimdeki olumsuzluk, özellikle gelişim geriliği olan özel gereksinimli çocukların yemek yeme ve deneme girişimlerini azaltır $(1,3,6,15)$.

Çocukların yeme zamanı ve yeme davranışları sorunlarının belirlenmesi ile gıda reddi, yeme zamanından kaçma, uyumsuzluk, yetersiz besin alımı gibi sorunların azalmasına yardımcı olur $(12,16)$. Yeme zamanı ve yeme sorunlarının değerlendirilmesi ve çözümü için bu sürecin çok yönlü ele alınması gerekir. Beslenme şeklinin belirlenmesi, beslenme davranışlarının düzenlenmesi, ailenin beslenme konusundaki rollerinin ve davranışlarının ele alınması çocuğun yeterli besin alımı açısından da gereklidir $(3,7,16,17)$. Sağlıklı, hasta ve engelli çocukların tümünde gelişen yeme ve yeme zamanı sorunları yeterli büyüme ve gelişmeyi engelleyebilir. Beslenme problemleri ve yeme davranışlarında yaşanan sorunların giderilmesi için

\footnotetext{
*Doç. Dr. Bülent Ecevit Üniversitesi Sağlık Bilimleri Fakültesi Hemşirelik Bölümü, Çocuk Sağlığı ve Hastalıkları Hemşireliği Anabilim Dalı Zonguldak/Türkiye. e-posta: meltemipekkurtuncu@gmail.com Orcid No: 0000-0003-3061-5236 ** Doktora Öğrencisi. Bülent Ecevit Üniversitesi Sağlık Bilimleri Enstitüsü Çocuk Sağ lığı ve Hastalıkları Hemşireliği Anabilim Dalı Doktora Programı, Zonguldak / Türkiye. Orcid No: 0000-0003-1980-5661
} 
Araştırma

çocuk ve ailenin birlikte ele alınması gerekir. Türk dilinde araştırmada yer alan örneklem grubunda yeme davranışlarını ve beslenme problemlerini ölçen bir ölçeme aracı yoktur. Bu çalışma ile çocukların yeme zamanı ve yeme davranışlarının belirlenmesi sayesinde bu örneklem grubunda yaşanan sorunların giderilebileceği düşünülmüştür.

\title{
Araştırmanın Amacı
}

$\mathrm{Bu}$ çalışma, Çocuklar İçin Yeme Davranışları Ölçeği’nin (The Children’s Eating Behavior Inventory/CEBI) Türk toplumundaki 2-12 yaş grubu engelli çocuklar için geçerli ve güvenilir bir ölçme aracı olup olmadığını belirlemek amacı ile yapild1.

\section{Araştırmanın Soruları}

- Türk toplumundaki 2-12 yaş grubu engelli çocuklar için geçerli ve güvenilir bir ölçme aracı mıdır?

- Çocuklar İçin Yeme Davranışları Ölçeği (CEBİ) Türkçe formunun iki ebeveynli, en az iki kardeşe sahip engelli çocukların yeme davranışlarını değerlendirmek için geçerli ve güvenilir bir ölçek midir?

\begin{abstract}
Araştırmanın Tipi
Yöntem

Engelli çocuğa sahip aileler tarafindan değerlendirilen çocuklar için yeme davranışları ölçeğinin Türkçe eşdeğerliğinin sağlanması ve geçerlik ve güvenirliğin sınanması amacıyla gerçekleştirilen bu çalışma metadolojik tipte bir çalışmadır.

\section{Araştırmanın Yapıldı̆̆ Yer ve Zaman}

$\mathrm{Bu}$ araştırma, Zonguldak il merkezinde bulunan dört özel eğitim ve rehabilitasyon hizmeti veren kurumdan çalışmanın yapılmasına izin veren iki özel eğitim ve rehabilitasyon merkezinde yapıldı. Özel eğitim ve rehabilitasyon merkezlerinin tümü haftanın altı günü eğitim vermektedir. Araştırma 01 Mart-31 Temmuz 2019 tarihleri arasında araştırmaya katılmayı kabul eden bu merkezlerde çocukları eğitim gören çalışmaya katılmayı kabul eden ebeveynler ile gerçekleştirildi.
\end{abstract}

Araştırmanın Evreni ve Örneklem Seçimi

Araştırmanın evrenini çalışmanın yürütülmesine izin veren her iki rehabilitasyon merkezinde özel eğitim ve rehabilitasyon için gelen 426 engelli çocuk vardır. Bu evrende en az iki çocuklu ve eşi ile birlikte yaşayan, engelli çocuğa sahip toplam 210 ebeveyn çalışma evrenini oluşturdu. Bu evrenden; bilinmeyen sıklıkla \%5 olasılıkla ve \%95 güven seviyesi ile belirlenen ve araştırmaya katılmayı kabul eden gönüllülerin tamamının örnekleme dâhil edilmesi planlandı. Ancak 210 kişiden ölçek madde sayısının 10 katı olan 190 ebeveyn örnekleme alındı. Örneklemin evreni temsil etme yüzdesi 90.476'dır. Bu araştırmada örneklem büyüklüğü Açıklayıcı Faktör Analizi (AFA) ve Doğrulayıcı Faktör Analizi (DFA) için ölçekte yer alan her madde başına 10 kişi olacak şekilde 10:1 $(\mathrm{n}=190)$ belirlendi $(18,19)$. Ölçekteki madde sayısı 19 olup örnekleme 190 engelli çocuğa sahip ebeveyn dâhil edildi.

\section{Araştırmaya Dâhil Edilme Kriterleri}

Ebeveynlerin araştırmaya dâhil edilebilmesi için tanılanmış herhangi bir ruhsal ya da mental bir hastalığı olmaması, Türkçe okuryazar olması, en az iki çocuğu olması ve eşleri ile birlikte yaşaması kriterleri arand1. Ebeveynin en az iki çocuklu olması ve eşleri ile birlikte yaşaması kriteri; ölçeğin orijinal formunda eşlere ve kardeşlere yönelik cevaplanacak maddelerin bulunması nedeni ile belirlendi.

\section{Veri Toplama Araçları}

Veriler araştırmacı tarafından hazırlanmış 11 sorudan oluşan Ebeveyn Bilgi Formu ve Çocuklar İçin Yeme Davranışları Ölçeği ile toplanmiştır.

Ebeveyn Bilgi Formu: Araştırmacı tarafından hazırlanmış engelli çocuğun yaşı, engel türü, engel derecesi, öğrenim durumu gibi değişkenleri, ebeveynin adı, yaşı ve yakınlık derecesini gibi değişkenleri içeren 11 soruluk bir formdur.

Çocuklar İçin Yeme Davranışı Ölçeği: Archer, Rosenbaum ve Streiner tarafindan 1991'de (1) geliştirilen orijinal form 40 maddeden oluşan bir formdur. Ölçeğin yapısında kardeş ve eşe yönelik maddeler mevcuttur. Ölçek medikal tedavi gerektiren ve engelliliğe sahip çocukların yeme davranışlarını belirlemek için geliştirilmiştir. Ölçek Orijinal formun revize edilmiş ölçek formu 19 maddeli, beşli likert tipte, üç faktörlü, her bir madde için evet hayır yanıtlı "Bu sizin için sorun oluyor mu?” sorusunu içeren ebeveyn değerlendirmesi gerektiren bir ölçektir.

\section{Verilerin Toplamast}

Veriler araştırmacı tarafından ebeveynlerin eğitim için gittiği rehabilitasyon merkezlerinde çocukların eğitim gördüğü sırada ebeveynler ile yüz yüze görüşme yöntemiyle gerçekleştirilmiştir. Veriler toplanmadan önce araştırmanın kimliği, araştırmanın amacı ve verilerin akademik amaçlı kullanılacağı bilgisi verilmiştir. Görüşmeler rehabilitasyon merkezinde ebeveynler için ayrılmış bekleme salonunda yaklaşık 15-20 dakikada toplanmıştır.

\section{Verilerin Analizi}

İstatistiksel analizler için NCSS (Number Cruncher Statistical System) 2007 programı kullanılmıştır. Çalışma verileri değerlendirilirken tanımlayıcı istatistiksel metodlar (ortalama, standart sapma, medyan, frekans, oran, minimum, maksimum) kullanılmıştır. Ölçek puanları arasındaki ilişkilerin değerlendirilmesinde Pearson Korelasyon Analizi kullanılmıştır.

Engelli çocuk aileleri için aileden aileye destek algısı ölçeğinin geliştirilmesinde Açıklayıcı Faktör Analizi, geçerlilik güvenilirlik değerlendirmelerinde Reliability Analiz ve Doğrulayıcı Faktör Analizi (Lisrel 8.8) yapılmıştır. Çalışmada yer alan KMO ölçütü, Alfa katsayısının değerlendirilmesinde kullanılan ölçütler ve Korelasyon katsayısının (r) değerlendirilmesinde aşağıdaki kriterlere göre yapılmıştır.

Kaiser-Meyer-Olkin (KMO ölçütünün değerlendirilmesinde; .90-1.00 arasında mükemmel; .80-.89 arasında oldukça iyi; .70-.79 arasında iyi; .60-.69 arasında orta; .50-.59 arasında zayıf ve $<.50$ olduğunda ise kabul edilemez olduğu belirtilmektedir (18,20). Alfa katsayısının değerlendirilmesinde; Alfa katsayıs1 $.00 \leq \alpha<.50$ güvenilir değil, .50 $\leq \alpha<.60$ düşük derecede güvenilir, .60 $\leq \alpha<.70$ orta düzeyde güvenilir, .70 $\leq \alpha<.80$ genel kabul gören düzeyde güvenilir, .80 $\leq \alpha<$ 
Araştırma

.90 yüksek derecede güvenilir, $.90 \leq \alpha<1.00$ mükemmel derecede güvenilir bir ölçektir (19). Korelasyon katsayısının (r) değerlendirilmesinde; .00-.25 arası çok zayıf; .26-.49 arası zayıf; .50-.69 arası orta; .70-.89 arası iyi ve .90-1.00 arası çok iyi olarak değerlendirilir (21).

\section{Araştırmanın Etik Boyutu}

Araştırma öncesinde Zonguldak Bülent Ecevit Üniversitesi İnsan Araştırmaları Etik Kurulu’ndan 12.02.2019/506 sayılı karar ile onam alınmıştır. Etik kurul onam sonrasında araştırmanın yürütüldüğü rehabilitasyon merkezlerinden kurum izinleri alınmıştır. Örneklemde yer alan bireylere araştırma hakkında bilgi verilerek yazılı ve sözlü onam alınmıştır.

\section{Bulgular}

Katılımcıların yaş ortalaması 37.40 \pm 6.73 , \%88.4'ü (n:168) anne, \%76.3'ü (n:145) ev hanımı ve \%46.3'ü (n: 88) ilkokul mezunudur. Engelli çocukların yaş ortalaması $8.76 \pm 4.10$ ve \%70.5'i (n:134) erkektir. Çocukların \%40’1 (n:76) zihinsel engelli, \%21.05'i (n:40) otistik engelli ve \%55.2'si (n: 105) orta ve \%26.3'ü (n: 50) ağır engellidir.

Çalışmanın geçerliliğinin sağlanması için kapsam ve yapı geçerlilik yöntemleri kullanılmıştır. Kapsam geçerliliği için Polit ve Beck'e göre (22) uzman görüş formu hazırlanmıştır. Polit ve Beck’e göre (22) sekiz uzman için kapsam geçerlik indeksi kestirim değeri .78 olarak belirlenmiştir (22,23). Ölçeğin toplam KGİ değeri .90'dır.

Yapılan analizler sonucunda ölçeğe ilişkin geçerlik-güvenirlik analizleri incelendiğinde; ölçek maddelerinin iç tutarlılığını gösteren Cronbach's alpha değeri .77 olarak saptanmıştır ve genel kabul edilebilir düzeyde güvenilir olduğu belirlenmiştir. Maddelere ilişkin düzeltilmiş madde-toplam korelasyon değerleri incelendiğinde ise \%40'ın altında olan madde olmadı̆̆ı görülmüştür.

Faktör analizi uygulandığında; ölçeğin Türkçe formunun beş faktör altında toplandığı ve açıklayıcılık katsayısının \%65.05 olduğu görülmektedir. Bu araştırmada ölçeğin yapı geçerliliği açıklayıcı ve doğrulayıcı faktör analizi ile değerlendirilmiştir. Açıklayıcı faktör analizi sonuçlarına göre; KMO =.71, $\mathrm{X}^{2}=137.54$ ve $\mathrm{p}<.001$ olarak belirlenmiştir (Tablo 1).

Tablo 1. Çocuklar İçin Yeme Davranışı Ölçeğinin KMO ve Bartlett Küresellik Testi Sonuçları

Kaiser-Meyer-Olkin Örneklem Yeterlilik Ölçümü

\section{.711}

\begin{tabular}{|c|c|c|}
\hline Bartlett Küresellik Testi & Ki kare & 1370.545 \\
\hline & Serbestlik derecesi & 171 \\
\hline & Anlamlilik & .001 \\
\hline
\end{tabular}

Faktör sayısına karar verirken, faktörlerin açıklandıkları toplam varyans yüzdeleri, anlamlı bileşim maddelerinin saptanması ve kaç faktör seçileceğine karar vermek için gerekli testler yapılmıştır. Faktör analizi sonucunda çocuklar için yeme davranışı ölçeği toplam varyansın \%65.05'ini açıklamaktadır.

Yamaç eğim grafiğine göre, faktör sayısı eğimin kaybolmaya başladığı ya da eğimi gösteren çizginin düzleşmeye başladığı noktada gösterilen bileşen sayısı olarak alınmıştır. Grafik 1 incelendiğinde eğim çizgisinin kırılma noktaları Faktör 5 'ten itibaren grafik çizgisinin düzleşmeye başladığı görülmüştür.

Özdeğerler toplamı; Faktör 1'de 4.39, varyans yüzdesi 23.11; Faktör 2'de 3.57, varyans yüzdesi 18.78; Faktör 3'te 1.77, varyans yüzdesi 9.32; Faktör 4'te 1.41, varyans yüzdesi 7.43 ve Faktör 5'te 1.22, varyans yüzdesi 6.42'dir. Tablo 2'de ölçeğe ait özdeğerler ve açıklanan toplam varyans sonuçları verilmektedir.

Tablo 2. Ölçeğe Ait Faktör Analizi Öz Değerleri ve Açıklanan Toplam Varyans Sonuçları

\begin{tabular}{lllll}
\hline & $\begin{array}{l}\text { Faktörde yer } \\
\text { alan maddeler }\end{array}$ & $\begin{array}{l}\text { Özdeğerler } \\
\text { toplamı }\end{array}$ & $\begin{array}{l}\text { Varyansın } \\
\text { yüzdesi }\end{array}$ & $\begin{array}{l}\text { Toplam } \\
\text { yüzdesi }\end{array}$ \\
\hline Faktör 1 (Aile alt boyutu) & $16,17,18,19$ & 4.39 & 23.11 & 23.11 \\
\hline Faktör 2 (Beceri alt boyutu) & $1,4,8,10,13$ & 3.57 & 18.78 & 41.89 \\
\hline Faktör 3 (Olumsuzluk alt boyutu) & $5,7,9$ & 1.77 & 9.32 & 51.21 \\
\hline Faktör 4 (Duygu alt boyutu) & $2,6,11^{*}$ & 1.41 & 7.43 & 58.64 \\
\hline Faktör 5 (İzin alt boyutu) & $3,12,14,15$ & 1.22 & 6.42 & 65.055 \\
\hline
\end{tabular}

${ }^{*}$ Ters ifadeler

Varimax döndürme yöntemi kullanılan AFA sonucunda ortaya çıkan beş faktörün yükleri .41 ile .88 arasında değişti.

Her bir faktör için cronbach alfa katsayıları .69 ile .80 arasındadır. Ölçeğin toplam cronbach alfa katsayısı .77 olup ölçek Türkçe eşdeğerlik için genel kabul edilebilir düzeyde güvenilir olarak değerlendirilmiştir. Faktörlerde toplanan maddelerin faktör yükleri ve cronbach alfa katsayıları Tablo 3 'te belirtilmektedir. 
Araştırma

Tablo 3. Çocuklar İçin Yeme Davranışı Ölçeği Faktör Yükü, Toplam Madde Faktör Yükü ve Cronbach Alfa Katsayıları

\begin{tabular}{|c|c|c|c|c|c|}
\hline 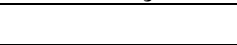 & Faktör 1 & Faktör2 & Faktör3 & Faktör4 & Faktör5 \\
\hline Soru 18 & .83 & .02 & .24 & .01 & .07 \\
\hline Soru 19 & .75 & -.03 & .24 & -.09 & .08 \\
\hline Soru 16 & .66 & .07 & .48 & -.02 & -.06 \\
\hline Soru 17 & .62 & .24 & -.08 & -.14 & .27 \\
\hline Soru 4 & .067 & .84 & -.11 & .12 & .07 \\
\hline Soru 13 & .23 & .77 & -.21 & .11 & -.01 \\
\hline Soru 1 & -.07 & .75 & -.18 & .20 & .10 \\
\hline Soru 8 & .04 & .55 & .32 & -.20 & .26 \\
\hline Soru 10 & .31 & .41 & .29 & .05 & .17 \\
\hline Soru 7 & .07 & -.05 & .88 & -.02 & -.04 \\
\hline Soru 9 & .15 & -.20 & .78 & -.07 & .06 \\
\hline Soru 5 & .25 & -.15 & .65 & -.18 & .04 \\
\hline Soru 11 & .02 & .00 & -.01 & -.78 & -.10 \\
\hline Soru 2 & -.17 & .34 & -.01 & .71 & .08 \\
\hline Soru 6 & .11 & .17 & -.38 & .71 & -.06 \\
\hline Soru 3 & -.06 & .12 & .08 & -.03 & .83 \\
\hline Soru 15 & .32 & .04 & .02 & .18 & .68 \\
\hline Soru 14 & .41 & .14 & -.04 & .08 & .53 \\
\hline Soru 12 & .27 & .38 & .00 & -.34 & .49 \\
\hline Cronbach alfa & .78 & .75 & .80 & .69 & .70 \\
\hline
\end{tabular}

Toplam Cronbach alfa katsayısı .77

$\mathrm{Bu}$ araştırmada güvenilirliğinin test edilmesinde Coranbach Alfa katsayısından yararlanılmıştır. Ayrıca ölçek maddelerinin alfa katsayısına ne derecede ve ne yönde etkide bulunduklarını saptayabilmek için "Değişken Silindiği Takdirde Ölçeğin Alfa Katsayısı" (Alpha if item deleted) değeri hesaplanmıştır. Maddelerin başlangıç ortak değerleri en düşük .43 en yüksek .69 olduğu saptanmıştır. (Tablo 4). Tablo 4'te herhangi bir değişken silindiği takdirde, geri kalan değişkenlerin iç tutarlılıklarını ve maddelerin ortak faktör varyansı gösterilmektedir.

Tablo 4: Çocuklar İçin Yeme Davranışları Ölçeği Faktörü Oluşturan Maddelerin Güvenilirliğe Etkileri

\begin{tabular}{|c|c|c|c|c|c|}
\hline & $\begin{array}{l}\text { Madde } \\
\text { silindiğinde ölçek } \\
\text { ortalaması }\end{array}$ & $\begin{array}{l}\text { Madde } \\
\text { silindiğinde } \\
\text { ölçek varyansı }\end{array}$ & $\begin{array}{l}\text { Düzeltilmiş } \\
\text { madde bütün } \\
\text { korelasyonu }\end{array}$ & $\begin{array}{l}\text { Madde } \\
\text { silindiğinde } \\
\text { cronbach alfa }\end{array}$ & $\begin{array}{l}\text { Ortak } \\
\text { faktör } \\
\text { varyansı }\end{array}$ \\
\hline Soru 1 & 44.40 & 88.519 & .56 & .75 & .66 \\
\hline Soru 2 & 44.50 & 91.649 & .53 & .76 & .66 \\
\hline Soru 3 & 45.18 & 9.136 & .44 & .75 & .72 \\
\hline Soru 4 & 44.68 & 84.148 & .63 & .74 & .74 \\
\hline Soru 5 & 45.79 & 93.841 & .63 & .76 & .54 \\
\hline Soru 6 & 44.51 & 95.239 & .53 & .77 & .69 \\
\hline Soru 7 & 45.84 & 94.221 & .61 & .76 & .78 \\
\hline Soru 8 & 45.48 & 89.576 & .47 & .74 & .52 \\
\hline Soru 9 & 45.93 & 95.026 & .57 & .76 & .68 \\
\hline Soru 10 & 45.94 & 86.322 & .58 & .74 & .53 \\
\hline Soru 11 & 44.86 & 93.919 & .45 & .77 & .62 \\
\hline Soru 12 & 45.59 & 9.628 & .57 & .75 & .75 \\
\hline Soru 13 & 44.87 & 85.520 & .62 & .74 & .71 \\
\hline Soru 14 & 45.78 & 85.583 & .43 & .74 & .57 \\
\hline Soru 15 & 45.36 & 87.497 & .50 & .74 & .60 \\
\hline Soru 16 & 46.04 & 89.366 & .62 & .74 & .68 \\
\hline Soru 17 & 45.65 & 88.059 & .57 & .74 & .54 \\
\hline Soru 18 & 46.08 & 88.535 & .69 & .74 & .75 \\
\hline Soru 19 & 46.11 & 9.921 & .51 & .75 & .64 \\
\hline
\end{tabular}

Çocuklar için yeme davranışları ölçeğine ilişkin beş alt boyutu oluşturan maddelerin, doğrulayıcı faktör analizi sonucundaki Path Diagramı Şekil 1'de görülmektedir. 
Araştırma

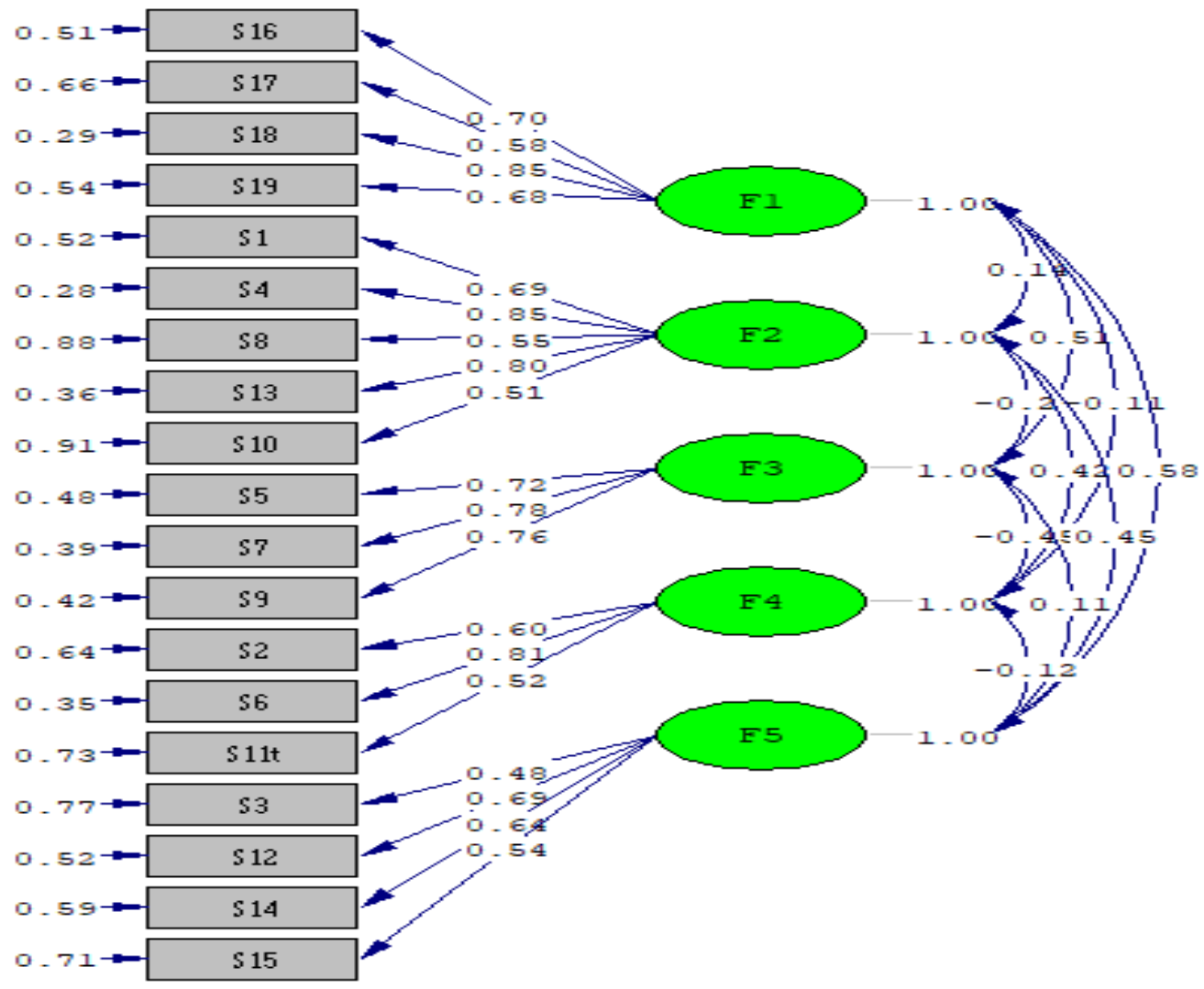

\section{Şekil 1. Çocuklar İçin Yeme Davranışları Ölçeğine İlişkin Doğrulayıcı Faktör Analizi Path Diagramı}

Modelin uyum ölçütleri incelendiğinde; RMSEA uyum ölçütü .09 olup, kabul edilebilir uyum göstermektedir. Diğer uyum ölçütlerinden RFI ölçütleri iyi uyum gösterirken; NFI, NNFI, CFI, IFI ve SRMR ölçütleri kabul edilebilir ve iyi uyum göstermektedir. Buna göre uyum ölçütlerinin iyi uyum ve kabul edilebilir uyum göstermeleri ve düzeltmeli ki-kare değerinin de kabul edilebilir uyum göstermesi, verilerin kabul edilebilir uyuma sahip olduğunu ve modelin istatistiksel olarak anlamlı ve geçerli olduğunu göstermektedir $(\mathrm{p}=.001 ; \mathrm{p}<.01)$ (Tablo 5). Çocuklar için yeme davranışları ölçeği modelinin test edilebilmesi için kurulan modelde yer alan boyutlar için uyum ölçütleri (uyum iyiliği indeksleri ve düzeltmeli Ki-kare $\mathrm{x}^{2} / \mathrm{df}$ değeri) Tablo 5 'te verilmektedir.

Tablo 5.Çocuklar İçin Yeme Davranışları Ölçeğine İlişskin Doğrulayıcı Faktör Analizi Uyum İyiliği İndeksleri

\begin{tabular}{lllll}
\hline Uyum Ölçütleri & İyi Uyum & Kabul Edilebilir Uyum & Modelin Sonuçları & Uyum \\
\hline RMSEA & $0<$ RMSEA $<.05$ & $.05 \leq$ RMSEA $\leq .10$ & .09 & Kabul Edilebilir \\
\hline NFI & $.95 \leq \mathrm{NFI} \leq 1$ & $.90 \leq \mathrm{NFI} \leq .95$ & .94 & Kabul Edilebilir \\
\hline NNFI & $.97 \leq \mathrm{NNF} \leq 1$ & $.95 \leq \mathrm{NNFI} \leq .97$ & .94 & Kabul Edilebilir \\
\hline CFI & $.97 \leq \mathrm{CFI} \leq 1$ & $.95 \leq \mathrm{CFI} \leq .97$ & .95 & Kabul Edilebilir \\
\hline IFI & $.97 \leq \mathrm{IFI} \leq 1$ & $.95 \leq \mathrm{IFI} \leq .97$ & .95 & Kabul Edilebilir \\
\hline RFI & $.90 \leq \mathrm{RFI} \leq 1$ & $.85 \leq \mathrm{RFI} \leq .90$ & .93 & Iyi uyum \\
\hline SRMR & $0 \leq \mathrm{SRMR} \leq .05$ & $.05 \leq \mathrm{SRMR} \leq .10$ & .06 & Kabul Edilebilir \\
\hline$\aleph^{2} /$ df & $0 \leq \mathrm{N}^{2} / \mathrm{df} \leq 2$ & $2 \leq \mathrm{N}^{2} / \mathrm{df} \leq 3$ & .30 & Kabul Edilebilir \\
\hline
\end{tabular}

\section{Tartışma}

$\mathrm{Bu}$ araştırmada çocuklar için yeme davranışları ölçeğinin geçerlik ve güvenirliğinin yapılması amaçlanmıştır. Araştırmaya dâhil olan engelli çocukların ebeveynleri büyük çoğunluğu kadın ve evli ve yaş ortalaması $37.40 \pm 6.73$ 'tür. Engelli çocukların yaş ortalaması $8.76 \pm 4.10$ olup çoğunluğu erkek ve zihinsel engellidir.

Bir değişkenin somut veya soyut özelliklerin ölçülmesinde kullanılacak ölçeğin standart bir ölçme aracı olması için vazgeçilmez iki temel özellik geçerlik ve güvenirliktir (22). Geçerlik bir ölçme aracının neyi ne kadar doğru olarak ölçtüğünün göstergesi olup, ölçme aracı ile elde edilen verilerin amaca yönelik, kullanılabilir olma özelliğidir. Verinin amaç için ne kadar yeterli ve uygun değerler olduğunu gösteren bir yargıdır. Geçerlikte cevaplanması beklenen temel soru "Maddeler amaç doğrultusunda ölçmek istenileni doğru olarak ölçebilir mi?” sorusudur. Bu amaçla geçerlik yöntemleri olarak kapsam geçerliği, ölçüt-bağımlı geçerlik ve yapı geçerliği kullanılmaktadır $(19,24,25)$.

Ölçeğin içerik geçerliğinin sağlanması amacıyla Kapsam Geçerlik İndeksi (KGi) hesaplanmıştır. Kapsam geçerliği ölçme aracında bulunan maddelerin ölçme aracının belirlemeyi amaçladığı konuları dengeli olarak denetleyecek kapsamda olma özelliğidir. Kapsam geçerliğinde temel amaç, ölçme aracında ölçülmek istenen kapsamı belirlemektir. Bunu belirlemek 
Araştırma

için ilgili alanda uzmanla işbirliği gerektirir ve uzmanlardan kapsam geçerliği için görüş alınır $(19,20,26)$. Hesaplanan ölçek KGİ değerinin .78 'in altında olması önerilmemekle birlikte .80 ve üzeri değer alması KGİ için yeterli olduğunu belirtmektedir $(25,27)$.

$\mathrm{Bu}$ araştırmada ölçek için sekiz kişilik uzman görüşü alınmıştır. Ölçekteki toplam KGİ .90 olarak bulunmuş ve kapsam geçerliğinin yeterli olduğu belirlenmiştir. Ölçekte maddelerin ölçüm amacına ne kadar ulaştığg, ölçülmesi istenen kavramı ne kadar doğru ölçtüğünün belirlenmesinde yap1 geçerliğine bakılmıştır $(24,26)$. Yap1 geçerliği, bir süreci ölçmede etkin ve bilimsel temellere dayalı kuram geliştirmektir (19). Bu ölçekte yapı geçerliği için faktör analizi uygulanmıştır.

Faktör analizi; benzer kavramı veya niteliği ölçen birçok maddenin farklı alt boyutlar altında toplanarak daha az sayıda faktör ile açıklanmasıdır. Faktör analizi, değişkenler arasındaki karmaşık ilişki modellerini daha basit modellerle keşfetmek ve değişkenler arasındaki ilişkinin temel yapısını tanımlamak amacıyla kullanılır $(19,20)$. Ölçek maddelerin farklı boyutlar altında birleşip birleşmediğini değerlendirirken kendi aralarında ilişki gösteren maddeler alt boyutları meydana getirirler. Faktör analizi için örneklem büyüklüğünün yeterli ve güvenilir sayıda olması gerekir $(18,20,25,28)$. Örneklem büyüklüğü belirlenirken incelenen değişken sayısının beş ya da on katı alınır. Yeterli örneklem sayısı ile ölçek maddelerindeki ilişkilerin güvenilir bir şekilde kestirilmesi sağlanmış olur. Ölçekteki maddelerin boyut yapısı açıklayıcı faktör analizi ve doğrulayıcı faktör analizi olmak üzere iki farklı yöntem ile yapılmaktadır $(19,24,27)$.

Açıklayıcı faktör analizi (AFA); Çok sayıda değişken içeren bir veri setinde, değişkenler ve faktörler arasındaki temel yapıyı ve yapıların doğasını açıklığa kavuşturmaya çalışan bir yöntemdir $(8,19,20)$. AFA birbiri ile ilişkili çok sayıda değişkeni bir araya getirerek kavramsal olarak anlamlı az sayıda faktör bulmayı amaçlar. AFA öncesi örneklem büyüklügünün değerlendirilmesi gerekir. Genel olarak faktörlerin etkisinin zayıf olması bekleniyorsa birey sayısını arttırmak gerekir $(9,18,25,28)$.

$\mathrm{Bu}$ amaçla faktör analizi yapabilmek için değişkenler arası korelasyon katsayılarının anlamlılı̆̆ AFA öncesinde örneklem büyüklüğü KMO ve Bartlett Testi ile değerlendirilir. KMO değerinin .60'ın üzerinde olması ve Barlett testinin anlamlı olması ölçeğin faktör analizi için uygun olduğunu göstermektedir $(19,25,28)$. Barlett testi sonucu eğer anlamlı değilse faktör analizinin kullanılması tekrar gözden geçirilmelidir. Faktör analizinde örneklem yeterlilik düzeyi KMO değeri ile belirlenir $(18,25,28)$.

$\mathrm{Bu}$ araştırmada KMO örneklem yeterlilik ölçümü değeri .71 ile örneklem büyüklüğü iyi düzeydedir. Bartlett küresellik test sonucunda $\mathrm{X}^{2}=1370.545 \mathrm{ve} \mathrm{p}<.001$ ile örneklem büyüklüğünün AFA için yeterli sayıda olduğu görülmüştür. Faktör analizi sonucunda engelli çocuk aileleri için aileden aileye destek algısı ölçeği toplam varyansın \%65.05'ini açıklamaktadır. Analiz sonucunda elde edilen varyans oranları ne kadar yüksekse, ölçeğin faktör yapısı da o kadar güçlüdür. Açıklanan varyansın yüksek olması, ilgili kavram veya yapı için tüm diğer değişkenlerle paylaşılan varyans miktarının iyi ölçüldüğünü belirtmektedir (18,28-30). Faktör analizinde açıklanan varyans oranlarının yüksek oluşu faktör yapısının da bir o kadar güçlü olduğunu gösterir. Analiz sonucunda belirlenen açıklanan varyans oranı düzeyi sosyal alanlarda \%40-60 arası olması yeterli kabul edilmektedir. Bu oran tıp veya ilaç sektörü gibi sağlık alanlarında \%95'e kadar çıkabilmektedir (18). Bu ölçeğin açıkladığı varyans oranı 65.05 ile yeterli olarak değerlendirilmiştir.

Açıklanan varyans ile birlikte ölçekte yer alan faktörlerin aldı̆̆ faktör yükleri faktör çözümüne yorumsal mantıkla en büyük katkıyı sağlar. Faktör yükü, madde ile faktör arasındaki korelasyon katsayılarıdır. Bir faktör altında toplanarak belirli bir yapıyı ölçen maddelerin ölçekte kalabilmesi için faktör yük değerinin belirli bir değer üstünde olması gerekir (18,28-30). Maddelerin faktör yükü ne kadar büyükse o kadar fazla önemlidir. Faktör ile madde arasındaki korelasyon .30'dan daha fazla ise faktörlerin ilişkili olduğu varsayılır $(18,19)$. Faktör yükü .45 ve üstü faktör yüküne sahip olması iyi olarak kabul edilir. Bu çalışmada faktör yükleri .41 ile .88 arasındadır. Araştırmada elde edilen veriler istenilen düzeydedir.

Araştırmada faktör sayısını saptamak için özdeğerin 1'den büyük olma kriteri olan Kaiser kriteri ve özdeğerlerin yamaç eğim grafiği kriterleri kullanılmıştır. Bir faktörün özdeğeri faktör matrisinde yer alan yüklerin kareleri toplamı olup, bu faktör tarafından hesaba katılan varyans miktarıdır $(18,19,25)$. Eğer bir faktör düşük özdeğere sahipse, değişkenlerin açıklanan varyansa çok az katkıda bulunduğu anlamına gelir. Özdeğer yükseldikçe, faktörün açıkladığı varyans da yükselir (18,19,25). Diğer bir ifade ile ele alınacak faktör sayısı 1'den büyük özdeğerlerin sayısıdır (18,19,25). Bu araştırmada yamaç eğim grafiğine göre, faktör sayısı eğimin kaybolmaya başladığı ya da eğimi gösteren çizginin düzleşmeye başladığı noktadan gösterilen bileşen sayısı olarak alınmıştır. Eğimin azaldığı noktadan sonraki faktörlerin varyansa katkısının daha az olacağından düşme noktasından sonraki faktörlerin dışlanmasını önerir $(18,19,25,28)$. Grafik 1'de yamaç eğim grafiği

incelendiğinde eğim çizgisinin kırılma noktaları faktör 5’ten itibaren grafik çizgisinin düzleşmeye başladığı görülmüştür. Bu ölçeğin Türkçe versiyonu Kaiser kriteri ve yamaç eğim grafiğine göre beş faktörlü olarak belirlenmiştir.

Doğrulayıcı faktör analizi (DFA); Açıklayıcı faktör analizi ile belirlenen faktörlerin, hipotezle belirlenen faktör yapılarına uygunluğunu test etmek üzere yararlanılan faktör analizidir $(19,25,31,32)$. Daha önce tanımlanmış ve sınırlandırılmış yapının veya modelin doğruluğunun test edildiği bir analizdir $(18,19,25)$. DFA, ölçülmek istenen yapı ya da kavrama ilişkin faktörler üretir. DFA yapı geçerliliğini değerlendirmek için kullanılır. AFA sonucunda elde edilen değişkenlerin hangi faktörle yüksek oranda ilişkili olduğunu test eder (18-20,31).

Doğrulayıcı faktör analizinde (DFA) Ki-kare testi ile modelin genel uyumuna bakılır. Ki-kare testi veriyle model arasındaki uyumun testidir. Ki-karenin anlamlı olmaması $\mathrm{x}^{2} / \mathrm{sd} \leq 3$ (bazı araştırmalara göre $\mathrm{x}^{2} / \mathrm{sd} \leq 5$ ) olması modelin uyumluluğunu gösterir (18). Ki-kare anlamlı dahi olsa, $\mathrm{x}^{2} / \mathrm{sd} \leq 3$ olması, modelin genel uyumunun kabul edilebilir olduğunu gösterir (18-20,31). Bu araştırmada $\mathrm{x}^{2} /$ sd oranı 3.303 olup modelin kabul edilebilir uyuma sahip olduğu belirlenmiştir. 
Araştırma

Yaklaşık hataların ortalama karekökü (RMSEA) değeri 0-1 arasında değer alır. .05'den küçük ve eşit ise mükemmel uyum, .08'e eşit ya da küçükse iyi uyum göstermektedir. Bu değerin .10'a eşit ya da küçük ise kabul edilebilir uyum olduğunu göstermektedir $(18,24,33)$. Bu çalışmada RMSEA değeri .09 olduğu ve modelin kabul edilebilir uyum gösterdiği belirlenmiştir.

Normlaştırılmış uyum indeksi (NFI) değerin altında, standart dışı uyum indeksi (NNFI) de değerin üstünde tahmin ettiğinden karşılaştırmalı uyum iyiliği (CFI) indeksi en fazla kullanılan indekstir. CFI değeri .95 ve üzeri ise kabul edilebilir uyumu, .97 ve üzeri ise iyi uyumu gösterir $(25,28,33)$. Bu çalışmada elde edilen tüm uyum iyiliği indeksleri dikkate alındığında uyum iyiliği indeksi değerleri .06 ve .10 arasında olup model uyumu kabul edilebilir uyum düzeyindedir.

Bir ölçeğin güvenirliği, bir değişkenin gerçek değerinin ölçme araçları ile doğru ve tam olarak ölçülebilme derecesidir. Güvenirlik, ölçme aracının ölçmeyi amaçladığı özelliğin ya da özelliklerin ne kadar kararlılıkla ölçülmekte olduğunun göstergesidir (25,33-37). Ölçme aracı geliştirmede güvenirlik sınanırken ölçeğin tutarlı, duyarlı ve kararlılık sağlanması gerekir. Bir ölçekteki maddelerin testin bütünü ile uyumlu olması ölçeğin tutarlılığını sağlar. Ölçülen özelliğin, aynı ölçekle farklı zamanlarda birkaç kez ölçümünde aynı sonuçların elde edilen durumu ise ölçeğin kararlılığıdır (18-20). Ölçeğin duyarlılığı ise ölçek veya sonuçlarının biriminin büyüklüğü ile ilgilidir. Birim aralığı küçükse ölçme daha duyarlıdır $(24,26,35)$. Bu araştırmada ölçek güvenilirliğinin test edilmesinde alfa katsayısı ve iç tutarlıktan yararlanılmıştır.

İç tutarlık, madde analizi madde toplam korelasyonu (r) bir maddeden alınan puanlar dizisi ile ölçeğin toplamından alınan puanlar dizisi arasında pozitif ve yüksek ilişki gözlenmesidir. Madde toplam korelasyon katsayısı .30 ve üstü maddelerin iyi olduğunu, .20-.30 arası maddelerin zorunluysa ölçme aracına alınabileceği, .20 ve altındaysa maddelerin ölçekten çıkarılması gerektiğini belirtmektedir (33-37). Bu çalışmada madde toplam korelasyonunun .41 ile .88 arasında ve istenilen aralıkta olduğu saptanmıştır.

Cronbach alfa güvenirlik katsayısı güvenilirlik hesaplarında sıkça kullanılan bir katsayıdır. Maddeler arası korelasyon ortalamasını da dikkate alarak iç güvenilirliği hesaplar (38). Ölçekte yer alan maddelerin varyansları toplamının genel varyansa oranlanması ile bulunan bir ağırlıklı standart değişim ortalamasıdır. Cronbach alfa katsayısı için genel kabul, hesaplanan değerin en az .70 olmasıdır $(18,38)$. Cronbach alfa katsayısı, ölçeğin her bir maddesinin kendi içinde aynı tutumu ölçtüğünün belirlenmesini sağlar (18,19,38). Cronbach alfa güvenirlik katsayısı $.00 \leq \alpha<.50$ güvenilir değil, $.50 \leq \alpha<.60$ düşük derecede

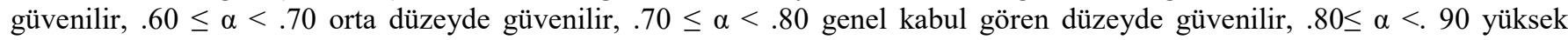
derecede güvenilir, $.90 \leq \alpha<1.00$ mükemmel derecede güvenilir olduğu belirtilmektedir $(18,19)$. Çalışmada ölçeğe ait her bir faktör için cronbach alfa katsayıları katsayıları .69 ile .80 arasında olup ölçeğin toplam cronbach alfa katsayısı .77 olarak belirlenmiştir. Elde edilen sonuçlara göre ölçeğin toplam güvenirlik katsayısının genel kabul gören düzeyde güvenilir olduğu saptanmış ve ölçeğin araştırmalarda bir bütün halinde kullanılması gerektiği düşünülmüştür. Yapılan analiz sonucunda ölçeğin Türkçe versiyonu beşli likert tipte, beş alt boyutlu ve her soru için evet hayır cevabından oluşan 'bu sizin için problem oluyor mu?” sorusunu içeren bir ölçek olup Türkçe dilinde geçerli ve güvenilir bir ölçme aracıdır.

\section{Sonuçların Uygulamada Kullanımı}

$\mathrm{Bu}$ ölçek kullanılarak 2-12 yaş grubu engelli çocukların yeme davranışları belirlenebilir. Yeme davranışlarına yönelik beslenme programları düzenlenebilir. Bu ölçek kullanılarak engelli çocukların yeme davranışları ve beslenme sorunları için deneysel çalışmalar yapılabilir.

Bilgilendirme
Yazarların Katkı beyanı; Fikir: MK, NA; Tasarım: MK, NA; Denetleme: MK; Veri Toplama ve İşleme: NA; Veri Analizi ve Yorumlama: MK, NA; Literatür tarama: NA; Makale yazma: MK, NA; Eleştirel inceleme: MK şeklindedir. Bu çalışma için etik kurul onayı alınmıştır (No: 12.02.2019/506). Araştırmaya herhangi bir fon desteği alınmamış olup, çalışma özgün araştırma türündedir ve araştırmacılar arasında çalışmaya bağlı olarak bir çıkar çatışması söz konusu değildir. Araştırmacılar, çalışmanın yapılması için gerekli izinleri veren kurumların yöneticilerine, çalışmaya katılmayı kabul eden engelli çocukların ailelerine, istatistiksel analizlere destek veren istatistik uzmanı Sayın Emire BOR'a, Çocuklar İçin Yeme Davranışları Ölçeği'nin kullanım iznini veren David Streiner'e, çalışmanın yapılmasına izin veren rehabilitasyon merkezi yöneticilerine, ölçeğe değerli görüşleri ile katkı yapan uzmanlara ve tüm katılımcılara teşekkür eder.

\section{Kaynaklar}

1. Archer LA, Rosenbaum PL, Streiner DL. The children's eating behavior inventory: reliability and validity results. Journal of Pediatric Psychology 1991;16(5):629-642.

2. Kerzner B, Milano K, MacLean W, Berall G, Stuart S, Chatoor I. Practical approach to classifying and managing feding difficulties. Pediatrics 2015;135(2):344-353.

3. Şahin S, Şahin ES, Öz NS, Atav PÜ, Kıvanç R. Pediatrik yeme veya yutma bozukluğu ve beslenme alışkanlığında aile rolünün etkisinin meta-analiz yöntemiyle incelenmesi. Hacettepe Üniversitesi Sağlık Bilimleri Fakültesi Dergisi 2019;6(2):200-214.

4. Kurt E, Örün E. Approaching the children with feeding problems. Güncel Pediatri 2016;14(3):129-135.

5. Marshall J, İll RJ, Ware RS, Ziviani J, Dodrill P. Multidisciplinary intervention for childhood feding difficulties. Journal of Pediatric Gastroenterology and Nutrition 2015;60(5):680-687.

6. Provost B, Crowe TK, Osbourn PL, McClain C, Skipper BJ. Mealtime behaviors of preschool children: Comparison of children with autismspectrum disorder and children with typical development. Physical \& Occupational Therapy in Pediatrics 2010;30(3):220-233. 
Araştırma

7. Aviram I, Atzaba-Poria N, Pike A, Meiri G, Yerushalmi B. Meal time dynamics in child feding disorder: The role of child temperament, parental sense of competence, and paternal involvement. Journal of Pediatric Psychology 2014;40(1):45-54.

8. Akdoğan R. A holistic approach to cope with depression and hopelessness for parents of special needs children. International Journal of Early Childhood Special Education 2016;8(2):134-150.

9. Balki S, Canbay Ö. Serebral palsili çocukların anne-babalarında depresyon seviyesini belirleyen değişkenler. Acıbadem Üniversitesi Sağl1k Bilimleri Dergisi 2012;3(4):242-249.

10. Didehbani N, Kelly K, Austin L, Wiechmann A. Role of parental stress on pediatric feding disorders. Children's Health Care 2011;40(2):85-100.

11. Erkorkmaz Ü, Yılmaz R, Demir O, Sanisoğlu SY, Etikan İ, Özçetin M. Çocuklarda yeme davranışı ve ebeveyn besleme tarzı arasındaki ilişkinin kanonik korelasyon analizi ile incelenmesi. Türkiye Klinikleri Journal of Medical Sciences 2013;33(1):138-148.

12. Shmaya Y, Eilat-Adar S, Leitner Y, Reif S, Gabis LV. Meal time behavior difficulties but not nutritional deficiencies correlate with sensory processing in children with autismspectrum disorder. Research in Developmental Disabilities 2017;66:27-33.

13. Mitchell GL, Farrow C, Haycraft E, Meyer C. Parental influences on children's eating behaviour and characteristics of successful parent-focussed interventions. Appetite 2013;60:85-94.

14. Bandini LG, Curtin C, Phillips S, Anderson SE, Maslin M, Must A. Changes in food selectivity in children with autism spectrum disorder. Journal of Autism and Developmental Disorders 2017;47(2):439-446.

15. Castro K, Perry IS, Ferreira GP, Marchezan J, Becker M, Riesgo R. Validation of the Brief Autism Mealtime Behavior Inventory (BAMBI) Questionnaire. Journal of Autism and Developmental Disorders 2019;49(6):2536-2544.

16. Heckathorn DE, Speyer R, Taylor J, Cordier R. Systematic review: non-instrumentals fallowing and feding assessments in pediatrics. Dysphagia 2016;31(1):1-23.

17. Sleddens EF, Kremers SP, Thijs C. The Children's Eating Behaviour Questionnaire: factorial validity and association with body mass index in Dutch children aged 6-7. International Journal of Behavioral Nutrition and Physical Activity 2008;5(1):49-58.

18. Karagöz Y. SPSSS ve AMOS 23 uygulamalı istatistiksel analizler. 2016; İstanbul: 1. Basım, Nobel Akademik.

19. Özdamar K. Ölçek ve test geliştirme yapısal eşitlik modellemesi. 2017; Eskişehir: Nisan Kitabevi.

20. Sümbüloğlu K, Akdağ B. İleri biyoistatistiksel yöntemler. 2009; Ankara: 1. Bask1, Hatiboğlu Yayınları.

21. Ok YS, Bektas M, Pokhrel P. Psychometric Properties of Turkish Version of the e-cigarette use outcome expectancies scale. Journal of Addictions Nursing 2020;31(2):124-133.

22. Polit DF, Beck, CT. The content validity index: Are you sure you know what's being reported? Critique and recommendations. Research in Nursing \& Health 2006;29(5):489-497.

23. Polit DF, Beck CT, Owen SV. Is the CVI an acceptable indicator of content validity? Appraisal and recommendations. Research in Nursing \& Health 2007;30(4): 459-467.

24. Erdoğan S, Nahcivan N, Esin MN. Hemşirelikte araştırma: süreç, uygulama ve kritik. 2014; İstanbul: Nobel Tıp Kitabevi.

25. Bektaş İ, Yardımcı F, Bektaş M, White KA. Psychometric properties of the Turkish version of nursing anxiety and selfconfidence with clinical decision making scale. Dokuz Eylül Üniversitesi Hemşirelik Fakültesi Elektronik Dergisi 2017;10(2):83-92.

26. Karakoç FY, Dönmez L. Ölçek geliştirme çalışmalarında temel ilkeler. Tıp Eğitimi Dünyası 2014;13(40):39-49.

27. Şimşek ÖF. Yapısal eşitlik modellemesine giriş temel ilkeler ve LISREL uygulamaları (Introduction to structural equation modeling, Lısrel fundamental principles and practices). 2010; Ekinoks yayınları, İstanbul.

28. Çokluk ÖŞ, Güçlü BŞ. Sosyal bilimler için çok değişkenli istatistik SPSS ve Lisrel uygulamaları. 2009; Ankara: 2. Baskı, Pegem Akademi.

29. Aldem M, Geçkil E. Astımlı çocuklarda ev dizaynı farkındalık ölçeği geliştirilmesi. Journal of Human Sciences 2019;16(1):285-300.

30. Geçkil T, Tikici M. Örgütsel demokrasi ölçeği geliştirme çalışması. Amme İdaresi Dergisi 2015;48(4):41-78.

31. Yaşlığlu MM. Sosyal bilimlerde faktör analizi ve geçerlilik: Keşfedici ve doğrulayıcı faktör analizlerinin kullanılması. Istanbul Üniversitesi Isletme Fakültesi Dergisi 2017;46 (Special Issue):74-85.

32. Özdamar K. Paket programları ile istatistiksel veri analizi (Çok değişkenli analizler SPSS-Minitab). 2012 ; Eskişehir: 4. Bask1, Kaan Kitabevi.

33. Çapık C. Geçerlik ve güvenirlik çalışmalarında doğrulayıcı factor analizinin kullanımı. Anadolu Hemşirelik ve Sağlık Bilimleri Dergisi 2014;17(3):196-205.

34. Dilsiz H, Dağ İ. Uyumsal yeme davranışının değerlendirilmesi: Bebeklik ve erken çocukluk dönemlerine yönelik iki yeni ölçeğin geliştirilme, Geçerlik ve güvenirlik çalışması. Journal of Current Pediatrics / Guncel Pediatri 2018;16(2):137-159.

35. Greco LM, O'Boyle EH, Cockburn BS, Yuan Z. Meta-analysis of coefficient alpha: A reliability generalization study. Journal of Management Studies 2018;55(4):583-618.

36. Şencan H. Sosyal ve davranışsal ölçümlerde güvenirlik ve geçerlik. 2005;Ankara: Seçkin Yayıncılık.

37. Can A. SPSS ile bilimsel araştırma sürecinde nicel veri analizi. 2014;Ankara: Pegem Akademi.

38. Aktürk Z, Acemoğlu H. Sağlık çalışanları için araştırma ve pratik istatistik, örnek problemler ve SPSS çözümleri. 2011; Erzurum: www.aile.net 